\title{
WHICH VIGOR VARIABLES CAN BE INFLUENCED BY PHOSPHATE FERTILIZATION IN MATURE Lagerstroemia indica L. TREES?
}

\author{
Severo Ivasko Júnior ${ }^{1 *}$, Rogério Bobrowski², Kátia Cylene Lombardi² \\ ${ }^{1 *}$ Universidade Federal do Paraná, Departamento de Engenharia Florestal, Curitiba, Paraná, Brazil, severoivasko@ gmail.com* \\ ${ }^{2}$ Universidade Estadual do Centro-Oeste, Departamento de Engenharia Florestal, Irati, Paraná, Brazil, rogerio@unicentro.br, \\ kclombardi@unicentro.br
}

Received for publication: 19/07/2018 - Accepted for publication: 26/06/2019

\begin{abstract}
Resumo
Quais variáveis do vigor podem ser influenciadas por adubação fosfatada em árvores maduras de Lagerstroemia indica L.? Os efeitos prejudiciais do processo de urbanização sobre o desenvolvimento das árvores nas cidades suscitam a busca por alternativas para conter os danos e manter os benefícios proporcionados pela floresta urbana. O presente estudo teve por objetivo caracterizar diferentes formas de expressão e elevação do vigor em Lagerstroemia indica L. Após as mensurações do vigor vegetativo, fisiológico e de florescimento das árvores, na estação de crescimento de 2016, foi realizada a calagem, e posterior aplicação dos tratamentos correspondentes a dosagens crescentes de fósforo em 50, 100, 150 e $200 \%$ do teor presente inicialmente no solo. Na estação de crescimento de 2017 foi realizada a remedição das condições de vigor visando avaliar o efeito da adubação sobre as árvores. Observou-se que para as variáveis comprimento do ramo, distância média entrenós, área foliar, largura e comprimento da floração, a maior dosagem de adubação fosfatada (200\%) proporcionou as maiores médias, enquanto as variáveis índice de cor verde escuro e clorofila a e b não foram afetadas pelos tratamentos. Conclui-se que o vigor vegetativo e de florescimento foi elevado significativamente pela adubação, enquanto o vigor fisiológico não foi responsivo a aplicação dos fertilizantes, de modo que a aplicação de $10 \mathrm{mg} / \mathrm{dm}^{3}$ de P proporcionou a maior expressão de vigor em $L$. indica.

Palavras-Chave: Arboricultura; calagem; floresta urbana; fertilização de árvores; revigoramento de árvores.
\end{abstract}

\begin{abstract}
The detrimental effects of the urbanization process on urban tree development provoke the search for alternatives to minimize damage and maintain benefits provided by urban forests. The present study aimed to characterize different forms of expression and increase of vigor in Lagerstroemia indica L. After measuring vegetative, physiological and blooming vigor in the 2016 growing season, liming and subsequent treatments of increasing phosphorus dosages at 50,100,150 and 200\% of the initial soil content were applied to trees. During the 2017 growing season, we measured the vigor conditions to evaluate the effects of fertilization on the trees. For the variables branch length, average distance internodes, leaf area, width and length of flowering, the highest phosphate fertilization (200\%) dosage provided the highest mean values, while the variables dark green color and chlorophyll $a$ and $b$ were unaffected by the treatments. In conclusion, the vegetative and flowering vigor significantly increased from fertilization, while the physiological vigor did not respond to fertilizer application, with the application of $10 \mathrm{mg} / \mathrm{dm}^{3}$ of $\mathrm{P}$ providing the highest vigor expression in L. indica.

Keywords: Arboriculture; liming; urban forest; tree fertilization; tree refreshment.
\end{abstract}

\section{INTRODUCTION}

Over the years, the urban environment has been suffering a series of negative impacts due to rapid growth of cities, with a significant transition from vast areas of natural ecosystem to areas covered by buildings, pavement and landfills (ROY et al., 2012). This process of urbanization has been undermining the balance within urban environments, constantly changing weather conditions, pollution rates and land cover (NURUZZAMAN, 2015).

These adverse conditions of urban environments are obstacles for the implantation and adaptation of tree elements within cities, as these environmental characteristics completely contradict those from the original environments of most species used in urban settings. The different typologies of urban forests are essential components for mitigating problems that arise from the urbanization process, as they can significantly affect the quality of life of resident populations (BALLINAS; BARRADAS, 2016). However, the planning of

FLORESTA, Curitiba, PR, v. 50, n. 1, p. 1021 - 1030, jan/mar 2020.

Ivasko Jr, S. et.al.

ISSN eletrônico 1982-4688

1021

DOI: $10.5380 /$ rf.v50 i1.60617 
establishment and management of afforestation is inadequate in most Brazilian cities, which makes it difficult to maximize the desired benefits.

Some of the most important activities that aim to maintain and improve the tree growth and development conditions in the urban environment are soil correction or liming and fertilization. Such practices are not only essential for satisfactory establishment of trees soon after planting, but also for maintaining their condition by supplementary nutrient addition through periodic fertilization (INGHAM et al., 2005). These technical procedures are important since the nutritional availability of most urban soils is not adequate for tree species development. Nevertheless, urban governments frequently neglect these practices (KIM et al., 2015).

Phosphorus is one of the most important nutrients for trees, being an essential element for various plant metabolic processes, such as carbohydrate metabolism and transport, also directly influencing the flowering process and root growth of trees (EREL et al., 2008; EREL et al., 2016).

According to Razaq et al. (2017), as phosphate fertilization favors tree root system development, responses to higher levels may indicate an improvement in the absorption of other nutrients available in the soil. For example, Kim et al. (2015), analyzing the effects of fertilization on four species from an urban forest in southeastern Korea, found that phosphorus fertilization improved the uptake and mineralization of NPK present in the rhizosphere.

In addition to positively influencing vegetative growth, phosphorus favors the aesthetic vigor of trees. Mahmoud et al. (2017), when analyzing the influence of leaf potassium fertilization on Olea europea L., found that the application of phosphorus stimulated the production of enzymes responsible for inducing flowering in the species.

In order to maintain tree quality through fertilization practices, evaluating urban trees is essential to determine if they are performing their environmental, economic, psychosocial and aesthetic functions properly. One of the most important parameters for such assessment is the analysis of tree vigor. Evaluating vigor is a good option for measuring the performance of a plant, as it indicates, among other parameters, the conditions of health, growth and development of an individual, whose characteristics also depend on their relationship with the environment where they are developing (HARRIS et al., 1999).

Of the components used to analyze vigor, we highlight the vegetative, physiological and flowering vigor. The vegetative vigor indicates the developmental condition of the vegetative structures of trees, such as leaves, branches, trunks and crowns (HARRIS et al., 1999). The physiological vigor evaluates the efficiency of the photosynthetic process of plants by quantifying the chlorophyll content present in leaves, which is the main pigment responsible for absorbing solar radiation and converting it into metabolic energy for plant development (NYAMSI et al., 2015). In addition, the flowering vigor of trees can be determined by measuring the intensity and size of inflorescences on each tree, which are structures that provide aesthetic beauty during the flowering period of the species (EREL et al., 2008).

Given the above, the hypothesis of this research was that mature Lagerstroemia indica trees can enhance vigor under the influence of phosphate fertilization. Therefore, the objective was to characterize different forms of expression and increase of vigor in L. indica and determine which phosphate fertilizer dosage has the greatest effect on the vegetative, physiological and flowering vigor of this species.

\section{MATERIAL AND METHODS}

\section{Study Area}

We conducted the study at Edgard Andrade Gomes public square located in the downtown area of Irati city, Paraná State. The municipality is inserted in the Mixed Ombrophilous Forest ecosystem, which makes up the Atlantic Forest Biome (SCHALLENBERGER et al., 2010).

According to the Köppen-Geiger climate classification, the region's climate is $\mathrm{Cfb}$ - Mesothermal Humid Subtropical. It has cool summers with average temperatures of $27.5^{\circ} \mathrm{C}$, winters with severe and frequent frosts with average temperatures of $8.3^{\circ} \mathrm{C}$, without a defined dry season (SCHALLENBERGER et al., 2010).

Fifteen Lagerstroemia indica L. trees located in the square were evaluated. This species presents the highest number of tree individuals in the downtown area. Trees had an average height of $4.20 \mathrm{~m}$, average DBH of $0.11 \mathrm{~m}$ and average crown diameter of $4.55 \mathrm{~m}$, with an average spacing of $3 \mathrm{~m}$ between each one, located on flat ground and surrounded by São Carlos grass and some herbs, as well as another tree species within the landscape treatment. 


\section{Methodological research procedure}

Prior to the application of treatments, we collected four soil samples per tree from a depth of $0.20 \mathrm{~m}$, each one corresponding to one of the four canopy projection rays, in the middle of the projection line and equidistant from each other.

These soil samples were homogenized and transformed into a representative sample of the soil condition of the five closest trees. In total, three samples were sent for routine analysis at the Terra de Floresta Laboratory of the Universidade Estadual do Centro-Oeste, accredited by the Comissão Estadual de Laboratórios de Análises Agronômicas do Estado do Paraná (CELA-PR).

From the soil analysis results, we determined the liming requirement and the amount of limestone to be applied in the soil. According to the recommendation adopted for ornamental plants, in Brazil, the value of soil base saturation (V\%) was increased to $60 \%$ with the application of fine-grained dolomitic limestone, 60 days before applying phosphate fertilization treatments. This was performed differently for the three groups of five trees, adapting the results from the hectare unit to the square meter of crown projection unit, with corresponding calculations shown in Table 1.

Tabela 1. Descrição da necessidade de calagem (NC) e respectiva quantidade de calcário aplicado (QC), em conjunto com os teores dos principais elementos quantificados na análise de solo, em cada amostra.

Table 1. Description of the need for liming (NL) and respective amount of applied limestone (AL), along with the contents of the main elements quantified in the soil analysis from each unit sampled.

\begin{tabular}{|c|c|c|c|c|c|c|c|c|}
\hline \multirow{2}{*}{ UNIT } & $\mathbf{K}^{+}$ & $\mathrm{Ca}^{2+}$ & $\mathrm{Mg}^{2+}$ & $\mathbf{H}^{+}+\mathbf{A l}^{3+}$ & \multirow{2}{*}{$\frac{\text { CPA }}{\mathbf{m}^{2}}$} & \multirow{2}{*}{$\begin{array}{l}\mathrm{V} \\
\%\end{array}$} & \multirow{2}{*}{$\begin{array}{c}\mathrm{NL} \\
\text { g.m }^{-2} \mathrm{CP}\end{array}$} & \multirow{2}{*}{$\begin{array}{l}\mathbf{A L} \\
\mathbf{K g}\end{array}$} \\
\hline & \multicolumn{4}{|c|}{ cmolc/dm ${ }^{3}$} & & & & \\
\hline Sample 1 & 0.16 & 2.70 & 1.62 & 7.93 & 10.75 & 36.10 & 361.71 & 4.31 \\
\hline Sample 2 & 0.16 & 2.69 & 1.57 & 8.48 & 11.34 & 34.26 & 404.88 & 5.09 \\
\hline Sample 3 & 0.22 & 3.72 & 1.94 & 8.30 & 9.84 & 41.47 & 320.49 & 3.50 \\
\hline
\end{tabular}

Legend: CPA: canopy projection area; V(\%): soil base saturation, NL: need for liming and AL: amount of limestone.

The equations used to determine the liming requirement and the amount of limestone were adapted to express the result in $\mathrm{g} / \mathrm{m}^{2}$ :

$$
N L\left(g \cdot m^{-2} \text { de } C P\right)=\left(\frac{(V \% \text { final }-V \% \text { initial }) * C E C * p}{100}\right) * 100
$$

in which: $N L$ is the need for liming, $C P$ the canopy projection, $V \%$ the soil base saturation, $C E C$ the soil cation exchange capacity and $p$ the depth of application factor (1.0).

$$
A L(g)=\left(N L *\left(\frac{L S}{100}\right) *\left(\frac{T L}{20}\right) *\left(\frac{100}{R P T N}\right)\right) * C P A
$$

in which: $A L$ is the amount of limestone, $N L$ the need for liming $\left(\mathrm{g} / \mathrm{m}^{2} \mathrm{CP}\right), L S$ the liming surface $(100 \%), T L$ the thickness of the layer to be corrected $(0.20 \mathrm{~m}), R P T N$ the relative power of total neutralization for liming $(90 \%)$ and $C P A$ the average canopy projection area $\left(\mathrm{m}^{2}\right)$.

We performed the vigor evaluation before and after applying the fertilizer treatments. The first evaluation was performed in the 2016 growing season (between November and January) and the second evaluation occurred in the 2017 growing season in the same period. Treatment dosages were created by using triple superphosphate $\left(46 \% \mathrm{P}_{2} \mathrm{O}_{5}\right)$.

Phosphate fertilization treatments were applied in mid-winter of 2017 (July 15), as L. indica blooms on new branches during the current growing season (HARRIS et al., 1999).

For the application of limestone and fertilizer treatments, we followed the procedure recommended by Harris et al. (1999). Under each tree canopy, ten holes of $0.10 \mathrm{~m}$ depth were drilled using an iron bar, spaced equidistantly and located at the last $1 / 3$ of the tree crown radius, close to the projection dripline. The amount of total fertilizer required was divided between the number of holes drilled per tree.

FLORESTA, Curitiba, PR, v. 50, n. 1, p. 1021 - 1030, jan/mar 2020. 


\section{Application of treatments}

To test the vigor response of 15 trees of $L$. indica, five different levels of phosphate fertilization were evaluated, considering a completely randomized design and the site as a homogeneous unit in relation to microclimatic and edaphic variables.

The phosphorus content estimated in the soil was used as a baseline, from which five phosphate fertilization treatments were defined, with three replications each. According to the scheme shown in Figure 1, the five treatments were:

Treatment 1: control, no phosphate fertilizer;

Treatment 2: phosphorus content measured in the soil increased by $50 \%$;

Treatment 3: phosphorus content measured in the soil increased by $100 \%$;

Treatment 4: phosphorus content measured in the soil increased by $150 \%$;

Treatment 5: phosphorus content observed in the soil increased by $200 \%$.

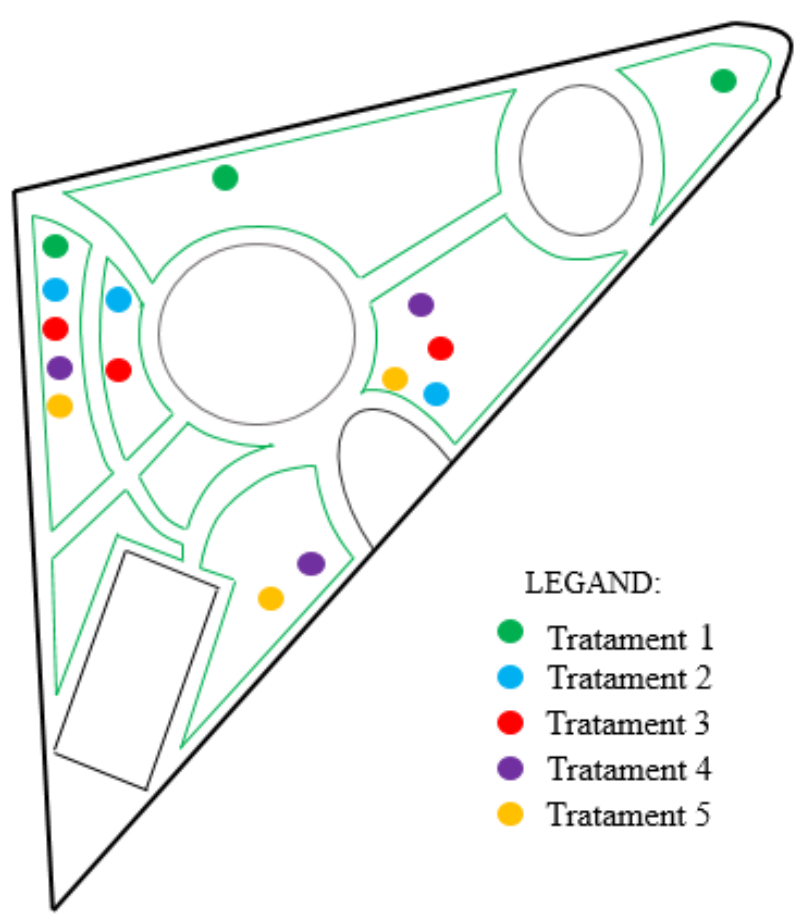

Figura 1: Representação dos tratamentos aplicados na praça.

Figure 1: Representation of treatments applied in the square.

Data was analyzed by the nonparametric Kruskal-Wallis test because no residual homoscedasticity was observed, even after data transformation. We used the software R, version 3.4.2, and the statistical package PMCMR, applying a post-hoc Tukey test at $5 \%$ probability of error to compare the means.

\section{Assessment of vigor characteristics}

\section{Vegetative vigor}

We sampled five branches from the central portion of the crown of each tree, at each cardinal axis of the crown projection. At each branch, we measured the length of the growing season and the average internode distance and estimated the average leaf area and leaf coloration (HARRIS et al., 1999).

To estimate the color and leaf area, we collected one leaf per sampled branch and evaluated five leaves per branch (20 leaves per tree). Leaves were scanned on an HP Deskjet F4180 printer and the images were analyzed using the Multispec $\circledast$ program to determine the average leaf area.

In ENVI ${ }^{\circledR}$ software, the same digitized images were used to determine the green intensity of leaves, and by transforming the quantified HSB values of the images, we determined the Dark Green Color Index (DGCI) using the following equation:

$$
D G C I=\left[\left(\frac{H-60}{60}\right)+(1-S)+(1-B)\right] / 3
$$


in which: $H$ is the hue, in degrees, ranging from $60^{\circ}$ (yellow) to $120^{\circ}$ (green), $\mathrm{S}$ the saturation, in decimal and $\mathrm{B}$ the brightness, in decimal.

\section{Physiological vigor}

For this parameter, we estimated the chlorophyll a and b contents present in the leaves. For this, three branch samples were collected per tree, and from each sample, one leaf was collected to extract a $7.85 \mathrm{~mm}^{2}$ sample from each leaf.

For pigment extraction, each leaf sample was inserted into a test tube containing $5 \mathrm{~mL}$ of dimethyl sulfoxide solvent (DMSO) and incubated in a water bath at $65^{\circ} \mathrm{C}$ for 150 minutes.

The absorbance of chlorophylls was determined in a Femto spectrophotometer, model 600, at $648 \mathrm{~nm}$ and $665 \mathrm{~nm}$ wavelengths, with subsequent determination of chlorophyll contents using the equations:

$$
\begin{aligned}
& C a=(14.85 *(A 665))-(5.14 *(A 648)) \\
& C b=(25.48 *(A 648))-(7.36 *(A 665))
\end{aligned}
$$

in which: $C a$ is the chlorophyll $a$ content (mg. $\mathrm{m}^{-2}$ of extract), $C b$ the chlorophyll $b$ content (mg.m $\mathrm{m}^{-2}$ of extract), A665 the absorbance value at wavelength $665 \mathrm{~nm}$ and A648 the absorbance value at wavelength 648 nm.

Flowering vigor

This parameter was evaluated by measuring the flowering intensity of trees. The procedure started by counting all flowering branches in each tree, followed by randomly sampling $10 \%$ of the total number of inflorescences on each individual to measure length and width.

\section{RESULTS}

\section{Vegetative vigor}

The means of the variables of increasing phosphorus dosages presented significant variations between treatments applied for branch length $\left(\mathrm{X}^{2}=19.07 ; p\right.$-value $\left.=0.0008\right)$, average internode distance $\left(\mathrm{X}^{2}=21.23 ; p\right.$ value $=0.0003)$ and leaf area $\left(\mathrm{X}^{2}=14.34 ; p\right.$-value $\left.=0.0063\right)$, however there was no difference for the dark green color index variable $\left(\mathrm{X}^{2}=7.70 ; p\right.$-value $\left.=0.1032\right)($ Table 2$)$. After applying the Bartlett test, the residuals were not homoscedastic for all measured variables, which justifies using nonparametric statistics.

Tabela 2. Estatística descritiva das variáveis que expressam o vigor vegetativo das árvores de Lagerstroemia indica, por tratamento.

Table 2. Descriptive statistics of the variables that express vegetative vigor of Lagerstroemia indica trees, by

\begin{tabular}{|c|c|c|c|c|c|c|c|c|c|}
\hline \multicolumn{6}{|c|}{ Branch Length (cm) (A) } & \multicolumn{4}{|c|}{ Average Internode Distance (cm) (B) } \\
\hline Treatments & $\mathrm{P}\left(\mathrm{mg} \cdot \mathrm{dm}^{-3}\right)$ & Minimum & Average & Maximum & $\mathrm{CV}(\%)$ & Minimum & Average & Maximum & $\mathrm{CV}(\%)$ \\
\hline $\mathrm{T} 1$ & 5 & 3.5 & $12.32 \mathrm{~b}$ & 21.1 & 43.14 & 1.3 & $3.10 \mathrm{~b}$ & 5.7 & 30.28 \\
\hline $\mathrm{T} 2$ & 7.5 & 9.1 & $14.63 \mathrm{ab}$ & 21.5 & 19.12 & 2 & $3.10 \mathrm{~b}$ & 4.8 & 21.76 \\
\hline $\mathrm{T} 3$ & 10 & 6.2 & $12.79 \mathrm{~b}$ & 24.6 & 27.88 & 1.4 & $2.87 \mathrm{~b}$ & 6.1 & 31.99 \\
\hline $\mathrm{T} 4$ & 12.5 & 7.5 & $13.19 \mathrm{~b}$ & 23.1 & 24.67 & 1.75 & $3.22 \mathrm{ab}$ & 5.2 & 23.03 \\
\hline T5 & 15 & 7.1 & $14.94 \mathrm{a}$ & 30.1 & 29.02 & 1.2 & $3.52 \mathrm{a}$ & 5.2 & 24.98 \\
\hline Average & & 3.5 & 13.57 & 30.1 & 28.76 & 1.2 & 3.16 & 6,1 & 26.41 \\
\hline \multicolumn{6}{|c|}{ Leaf Area $\left(\mathrm{cm}^{2}\right)(\mathrm{C})$} & \multicolumn{4}{|c|}{ Dark Green Color Index (D) } \\
\hline Treatments & $\mathrm{P}\left(\mathrm{mg} \cdot \mathrm{dm}^{-3}\right)$ & Minimum & Average & Maximum & $\mathrm{CV}(\%)$ & Minimum & Average & Maximum & $\mathrm{CV}(\%)$ \\
\hline $\mathrm{T} 1$ & 5 & 5.48 & $7.93 \quad b$ & 12.12 & 23.14 & 0.42 & $0.47 \mathrm{a}$ & 0.55 & 7.84 \\
\hline $\mathrm{T} 2$ & 7.5 & 6.39 & $8.15 \mathrm{ab}$ & 11.21 & 19 & 0.38 & $0.51 \mathrm{a}$ & 0.56 & 9.1 \\
\hline $\mathrm{T} 3$ & 10 & 6.13 & $8.82 \mathrm{ab}$ & 11.99 & 19.75 & 0.39 & $0.49 \mathrm{a}$ & 0.54 & 9 \\
\hline $\mathrm{T} 4$ & 12.5 & 7.56 & $9.79 \mathrm{ab}$ & 12.65 & 17.36 & 0.26 & $0.44 \mathrm{a}$ & 0.56 & 24.21 \\
\hline $\mathrm{T} 5$ & 15 & 7.69 & $10.29 \mathrm{a}$ & 13.43 & 19.65 & 0.28 & $0.45 \mathrm{a}$ & 0.55 & 17.38 \\
\hline Average & & 5.48 & 9.00 & 13.43 & 19.78 & 0.26 & 0.47 & 0.56 & 13.51 \\
\hline
\end{tabular}
treatment.

FLORESTA, Curitiba, PR, v. 50, n. 1, p. 1021 - 1030, jan/mar 2020. 
With the exception of the dark green color index (Table 2- D), the other variables that express vegetative vigor were significantly influenced by the treatment that increased phosphorus contents by $200 \%$, totaling $15 \mathrm{mg} / \mathrm{dm}^{3}$ of the element in the soil (Table $2-\mathrm{A}, \mathrm{B}$ and $\mathrm{C}$ ).

\section{Physiological vigor}

We found no significant differences between the chlorophyll a $\left(\mathrm{X}^{2}=3.88 ; p\right.$-value $\left.=0.4223\right)$ and $\mathrm{b}\left(\mathrm{X}^{2}\right.$ $=2.81 ; p$-value $=0.5900)$ contents $($ Table $3-\mathrm{A}$ and $\mathrm{B})$.

Tabela 3. Estatística descritiva das variáveis que expressam o vigor fisiológico das árvores de Lagerstroemia indica, por tratamento.

Table 3. Descriptive statistics of the variables that express the physiological vigor of Lagerstroemia indica trees, by treatment.

\begin{tabular}{cccccccccc}
\hline \multicolumn{4}{c}{ Chlorophyll $\boldsymbol{a}\left(\mathbf{m g . m}^{-2}\right.$ of extract) $\mathbf{( A )}$} & \multicolumn{4}{c}{ Chlorophyll $\boldsymbol{b}$ (mg.m $\mathbf{m}^{-2}$ of extract) $(\mathbf{B})$} \\
\hline Treatments & $\mathrm{P}\left(\mathrm{mg} / \mathrm{dm}^{3}\right)$ & Minimum & Average & Maximum & CV $(\%)$ & Minimum & Average & Maximum & CV $(\%)$ \\
\hline T1 & 5 & 0.26 & $1.44 \mathrm{a}$ & 2.38 & 52.95 & 0.01 & $0.58 \mathrm{a}$ & 1.71 & 110.06 \\
$\mathrm{~T} 2$ & 7.5 & 0.27 & $1.51 \mathrm{a}$ & 2.43 & 61.09 & 0.01 & $0.65 \mathrm{a}$ & 1.91 & 131.15 \\
$\mathrm{~T} 3$ & 10 & 0.23 & $1.72 \mathrm{a}$ & 2.56 & 45.08 & 0.08 & $0.56 \mathrm{a}$ & 1.79 & 100.01 \\
$\mathrm{~T} 4$ & 12.5 & 1.14 & $1.67 \mathrm{a}$ & 2.24 & 24.56 & 0.02 & $0.61 \mathrm{a}$ & 1.2 & 77.27 \\
T5 & 15 & 0.94 & $1.39 \mathrm{a}$ & 2.07 & 31.46 & 0.07 & $0.89 \mathrm{a}$ & 1.33 & 44.81 \\
\hline Average & & 0.23 & 1.55 & 2.56 & 43.03 & 0.01 & 0.66 & 1.91 & 92.66 \\
\hline
\end{tabular}

Legend: P (mg.dm $\left.{ }^{-3}\right)$, total phosphorus content in soil after fertilization application and CV (\%), coefficient of variation; Averages followed by identical letters did not differ significantly by Tukey test $(p>0.05)$.

\section{Flowering vigor}

The increasing phosphorus dosages showed that the averages corresponding to flowering vigor showed significant variations between treatments applied for length $\left(\mathrm{X}^{2}=59.17 ; p\right.$-value $\left.=4.34^{-12}\right)$ and flowering width $\left(\mathrm{X}^{2}=9.96 ; p\right.$-value $\left.=0.041\right)($ Table 4$)$

Tabela 4. Estatística descritiva das variáveis que expressam o vigor de florescimento das árvores de Lagerstroemia indica, por tratamento.

Table 4. Descriptive statistics of the variables that express the flowering vigor of Lagerstroemia indica trees, by treatment.

\begin{tabular}{|c|c|c|c|c|c|c|c|c|c|}
\hline \multicolumn{6}{|c|}{ Flowering Length $(\mathrm{cm})(\mathrm{A})$} & \multicolumn{4}{|c|}{ Flowering Width $(\mathrm{cm})(\mathrm{B})$} \\
\hline Trearments & $\mathrm{P}\left(\mathrm{mg} / \mathrm{dm}^{3}\right)$ & Minimum & Average & Maximum & $\mathrm{CV}(\%)$ & Minimum & Average & Maximum & $\mathrm{CV}(\%)$ \\
\hline $\mathrm{T} 1$ & 5 & 8 & $12.84 \mathrm{~b}$ & 19.3 & 23.57 & 4.80 & $7.77 \quad b$ & 11.10 & 22.65 \\
\hline $\mathrm{T} 2$ & 7.5 & 9.3 & $13.25 \mathrm{~b}$ & 18.2 & 16.92 & 6.90 & $8.64 \mathrm{~b}$ & 11.70 & 13.61 \\
\hline T3 & 10 & 6.2 & $11.48 \mathrm{~b}$ & 17.2 & 26.12 & 3.90 & $7.25 \quad b$ & 9.60 & 23.86 \\
\hline $\mathrm{T} 4$ & 12.5 & 9.2 & $14.54 \mathrm{ab}$ & 19 & 16.03 & 6.30 & $8.90 \quad b$ & 11.90 & 16.20 \\
\hline $\mathrm{T} 5$ & 15 & 11.4 & $16.35 \mathrm{a}$ & 26.5 & 15.15 & 7.20 & $9.84 \mathrm{a}$ & 13.60 & 13.04 \\
\hline Average & & 6.20 & 13.69 & 26.50 & 19.56 & 3.90 & 8.48 & 15.00 & 17.88 \\
\hline
\end{tabular}

Legend: $\mathrm{P}\left(\mathrm{mg} \cdot \mathrm{dm}^{-3}\right)$, total phosphorus content in soil after fertilization application and CV (\%), coefficient of variation; Averages followed by identical letters did not differ significantly by Tukey test $(p>0.05)$.

The flower length (Table 4-A) and width (Table 4-B) were significantly influenced by the treatment with $200 \%$ increase of soil phosphorus content, although for flower length this treatment did not differ from T4. As previously mentioned, the soil had $5 \mathrm{mg} / \mathrm{dm}^{3}$ of $\mathrm{P}$ before fertilization, so the best results tended to correspond to the application of $200 \%$ phosphorus $\left(10 \mathrm{mg} / \mathrm{dm}^{3}\right.$ of P), totaling $15 \mathrm{mg} / \mathrm{dm}^{3}$ present in the soil after treatment application.

\section{DISCUSSION}

\section{Vegetative vigor}

The response of vegetative vigor to the application of phosphate fertilization could indicate a nutritional deficiency of phosphorus in the trees studied. According to Brunetto et al. (2015), when nutritional availability is low, trees tend to prioritize their reproductive structures over vegetative ones, since phosphorus, a highly mobile element, tends to be redistributed from leaves to flowers. This natural process of phosphorus redistribution from leaves to flowers, and the response to the higher amount in the soil help to affirm that this element could be 
lacking in the evaluated trees, as there is periodic removal of biomass underneath trees and no history of fertilization in the square.

The positive relationship between the increased amount of applied phosphorus and improvement of tree vegetative vigor may have also occurred indirectly, as phosphate fertilizer application could have increased the amount of other nutrients in the soil. According to Chen et al. (2015), the addition of phosphorus favors nitrogen availability in the soil, which in turn is closely related to the development vegetative structures.

However, it is important to consider a number of processes that can negatively influence the response of tree vigor to fertilization practices, such as nutrient leaching and soil compaction. For Logsdon and Sauer (2017), besides the superficial loss of nutrients from water runoff, compaction restricts plant growth by hindering water infiltration and aeration in the soil, which impairs solubilization of applied nutrients and consequently makes it difficult for trees to absorb them.

Hobbie et al. (2014) found that the leaves of Acer platanoides, Acer $x$ fremanii, Fraxinus pennsylvanica, Quercus bicolor and Tilia cordata showed rapid decomposition, losing $80 \%$ of initial mass and releasing more than half of their phosphorus content after one year. Therefore, they concluded that nutrient reuse, especially for urban deciduous trees, is essential for their successful development, as the decomposition and maintenance of leaves under trees can significantly reduce the need for fertilizer input (mainly phosphorus). Although $L$. indica is a deciduous species, the elements present in the leaves are not reused by the trees after leaves fall, since they are constantly removed from the square by residents or the city.

Another important aspect regarding plant responses to increased phosphorus is that high rainfall precipitates soil phosphorus removal because this element is easily leached (HOBBIE et al., 2014). On the other hand, that can positively affect the efficiency of phosphorus use, since this nutrient is not readily available for absorption by trees in many phosphate fertilizers. Thus, rainfall accelerates element release into the soil, making it available and soluble near the roots (LOGSDON; SAUER, 2017).

According to Hobbie et al. (2014), the application of phosphate fertilizer mainly affects the development of the tree root system. Accordingly, more developed and vigorous roots tend to increase the absorption efficiency of not only phosphorus, but of other nutrients as well. Thus, tree responses to higher levels of phosphorus may indicate an improvement in the absorption of other available nutrients in the soil, favoring the vigor condition of the species overall.

Competition between trees in the urban environment also affects phosphorus absorption. In the square, besides $L$. indica trees that are distributed $+3.0 \mathrm{~m}$ apart, these trees also compete with other nearby tree species. Fang et al. (2017) concluded that Cunninghamia lanceolata trees that were located farther apart presented higher amounts of phosphorus in their rhizosphere and leaves than in trees located more closely together, thus the lower tree density reduced competition for phosphate fertilizer and consequently favored the use of phosphorus for tree development.

However, as the response to fertilization was most significant for the highest dosage, a more detailed experiment should be conducted, considering more dosages and applying even higher phosphorus dosages in order to establish which phosphorus fertilization dosage would be limited by competition between nutrients in the soil under adult trees in full growth conditions in green urban areas.

Although there are several factors that can influence tree responses to experimental field conditions, and it is impossible to isolate them all, these studies are essential for understanding the behavior of tree responses to a range of factors (CALFAPIETRA et al., 2017) and how urban tree fertilization can maintain tree vigor by preventing metabolic deficiencies and injuries.

\section{Physiological vigor}

The fact that there were no significant differences between phosphate fertilization levels regarding physiological vigor may indicate that internal metabolic processes involving leaf pigment production, specifically chlorophyll, are occurring properly. Thus, nutrient supply for the performance of this physiological activity occurred normally in the species, regardless of the amount of fertilizer applied to the soil.

The high CV values (\%) can be explained by the fact that the treatments presented significant standard deviation, mainly regarding the chlorophyll $b$ levels.

In general, environmental conditions have the greatest influence on the physiological responses of plants. According to Zhang et al. (2016), species that grow in places where the radiation incidence is low develop resources that improve the efficiency of light energy uptake, such as increased chlorophyll content or leaf area. Therefore, the fact that chlorophyll contents did not vary in the present study indicates that these adaptations were not necessary for $L$. indica, and these resources did not influence the expression of other variables, such as leaf area of the species.

FLORESTA, Curitiba, PR, v. 50, n. 1, p. 1021 - 1030, jan/mar 2020. 
It is clear that chlorophyll $a$ levels were always higher than chlorophyll $b$ levels, regardless of the analyzed treatment. According to Shibghatallah et al. (2013), this occurs since chlorophyll a contributes more to the photosynthesis process than chlorophyll $\mathrm{b}$, and is therefore required more in the leaves, as type a pigment absorbs the wavelengths ranging from violet to blue and orange to red in the visible spectrum, while accessory pigments, including chlorophyll $b$, absorb energy at other wavelengths.

\section{Flowering vigor}

The flowering vigor was favored by higher phosphorus contents, possibly since this element directly participates in the metabolic processes that affect the expression of inflorescences. According to Erel et al. (2016), this element is essential for carbohydrate synthesis, which in turn directly influences flower quality, with higher carbohydrate levels producing better tree flowering.

The higher levels of phosphorus needed for flowering development can be explained by the importance of this nutrient for flower formation. For Martinez et al. (2003), nitrogen and potassium concentrations are similar between leaves and flowers, indicating that these organs demand the same amount of these nutrients. However, the phosphorus concentration is higher in flowers because this element is mobile in phloem, thus accumulating in the reproductive organs, where it influences pollen tube growth, pollen grain maturation and intense metabolism of the first phase of fruit formation.

Studies that show the response of trees to increased dosages of certain nutrients are fundamental for applying determining adequate dosages of fertilizer, especially since the effect of fertilization is linked to local soil characteristics and nutritional requirements of species (FERRINI; BAIETTO, 2006). Malek and Mustapha (2013) emphasize that the rational application of nutrients is essential for meeting the nutritional needs of tree species to improve vigor and quality, while minimizing environmental impacts and avoiding overuse of fertilizers.

\section{CONCLUSIONS}

Based on the results obtained, it was possible to conclude that:

- Phosphate fertilization increased the expression of all variables related to vegetative vigor, except for the dark green color index. In addition, phosphorus application also increased flowering vigor.

- The physiological vigor of L. indica did not respond to the application of different phosphate dosages, indicating that this is not a good parameter for evaluating the general state of these trees.

- The application of $200 \%$ of the soil phosphorus content, corresponding to $10 \mathrm{mg} / \mathrm{dm}^{3}$, provided the highest increase of vegetative and flowering vigor in $L$. indica, although this dosage did not differ significantly from the initial 50\% increase (Treatment 2) for the variables branch length and leaf area.

\section{ACKNOWLEDGMENTS}

We thank CAPES for granting a scholarship to the first author of this research.

\section{REFERENCES}

BALLINAS, M.; BARRADAS, V. L. The urban tree as a tool to mitigate the urban heat island in Mexico City: A simple phenomenological model. Journal of Environmental Quality, v. 45, n. 1, p. 157-166, 2016.

BOBROWSKI, R. A floresta urbana e a arborização urbana. In: BIONDI, D. Floresta Urbana, v. 1., Curitiba, pp. 81-108. 2015.

BRUNETTO, G.; NAVA, G. AMBROSINI, V.G.; COMIN, J. J.; KAMINSKI, J. The pear tree response to phosphorus and potassium fertilization. Revista Brasileira de Fruticultura, Jaboticabal, v.37, n.2, p.507- 516, 2015.

CALFAPIETRA, C.; GUIDOLOTTI, G.; CHURKINA, G.; GROTE, R. Urban tree physiology: methods and tools. In: FERRINI, F.; VAN DEN BOSCH, C. C.; FINI, A. Routledge handbook of urban forestry. New York: Taylor \& Francis Group, 2017. p. 225-236.

CHEN, F. S.; NIKLAS, K. J.; LIU, Y.; FANG, X. M.; WAN, S. Z.; WANG, H. Nitrogen and phosphorus additions alter nutrient dynamics but not resorption efficiencies of Chinese fir leaves and twigs differing in age. Tree Physiology, v. 35, n. 10, p. 1106-1117, 2015. 
EREL, R.; DAG, A.; BEN-GAL, A.; SCHWARTZ, A.; YERMIYAHU, U. Flowering and fruit set of olive trees in response to nitrogen, phosphorus and potassium. Journal of the American Society for Horticultural Science, Alexandria, v. 133, n. 5, p. $639-647,2008$.

EREL, R.; YERMIYAHU, U.; YASUOR, H.; CHAMUS, D. C.; SCHWARTZ, A.; BEN-GAL, A.; DAG, A. Phosphorous Nutritional Level, Carbohydrate Reserves and Flower Quality in Olives. PloS One, Berkeley, v. 11 , n. 12, p. $1-19,2016$

FANG, X. M.; ZHANG, X. L.; ZONG, Y. Y.; ZHANG, Y.; WAN, S. Z.; BU, W. S.; CHEN, F. S. Soil phosphorus functional fractions and tree tissue nutrient concentrations influenced by stand density in subtropical Chinese fir plantation forests. PLoS One, Berkeley, v. 12, n. 10, 2017.

FERRINI, F.; BAIETTO, M. Response to fertilization of different tree species in the urban environment. Arboriculture \& Urban Forestry, Champaign, v. 32, n. 3, p. 93-99, 2006.

HARRIS, R. W.; CLARK, J. R.; MATHENY, N. P. Arboriculture: integrated management of landscape trees, shrubs, and vines, v. 3, Prentice Hall, New Jersey. 1999.

HOBBIE, S. E.; BAKER, L. A.; BUYARSKI, C.; NIDZGORSKI, D.; FINLAY, J. C. Decomposition of tree leaf litter on pavement: implications for urban water quality. Urban Ecosystems, New York, v. 17, n. 2, p. 369 385,2014

INGHAM, S. C.; FANSLAU, M. A.; ENGEL, R. A.; BREUER, J. R.; BREUER, J. E.; WRIGHT, T. H.; REITH-ROZELLE, J. K.; ZHU, J. Evaluation of Fertilization-to-Planting and Fertilization-to-Harvest Intervals for Safe Use of Noncomposted Bovine Manure in Wisconsin Vegetable Production, Journal of Food Protection, Des Moines, v. 68, n. 6, p. 1134 - 1142, 2005.

KIM, C.; JEONG. J.; PARK, J. H.; MA, H. S. Growth and nutrient status of foliage as affected by tree species and fertilization in a fire-disturbed urban forest. Forests, Basel, v. 6, n. 6, p. $2199-2213,2015$.

LOGSDON, S. D.; SAUER, P. Improved or unimproved urban areas effect on soil and water quality. Water, Basel, v. 9, n. 4, p. $247-253,2017$.

LORENZI, H.; SOUZA, H. M.; TORRES, M. A. V.; BACHER, L. B. Árvores exóticas no Brasil: madeireiras, ornamentais e aromáticas, v. 1, Plantarum, Nova Odessa. 2003.

MAHMOUD, T. S. M.; MOHAMED, E. S. A.; EL-SHARONY, T. F. Influence of Foliar Application with Potassium and Magnesium on Growth, Yield and Oil Quality of "Koroneiki" Olive Trees. American Journal of Food Technology, Dubai, v. 12, n. 3, p. 209-220, 2017.

MALEK, B. K.; MUSTAPHA, S. Response of Arbequina olive tree to reasonable fertilization. African Journal of Agricultural Research, Washington, v. 8, n. 29, p. 3911 - 3920, 2013.

MARTINEZ, H. E. P.; SOUZA, R. B.; BAYONA, J. A.; VENEGAS, V. H. A.; SANZ, M. Coffee-tree floral analysis as a mean of nutritional diagnosis. Journal of Plant Nutrition, New York, v. 26, n. 7, p. 1467 - 1482 , 2003.

NURUZZAMAN, M. D. Urban heat island: Causes, effects and mitigation measures - A review. International Journal of Environmental Monitoring and Analysis, Londres, v. 3, n. 2, p. 67 - 73, 2015.

NYAMSI, W. W.; ESPINAR, B.; BLANC, P.; WALD, L. Estimating the photosynthetically active radiation under clear skies by means of a new approach. Advances in Science Research, Washington, v. 12, n. 1, p. 5 $10,2015$.

RAZAQ, M.; ZHANG, P.; SHEN, H. Infuence of nitrogen and phosphorous on the growth and root morphology of Acer mono. PloS One, Cambridge, v. 12, n. 2, p. 1 - 13, 2017.

ROY, S.; BYRNE, J.; PICKERING, C. A systematic quantitative review of urban tree benefits, costs, and evaluation methods across cities in different climatic zones. Urban Forest and Urban Greening, Amsterdam, v. 11, n. 4, p. $351-363,2012$.

SCHALlENBERGER, L. S.; ARAUJO, A. J.; ARAUJO, M. N.; DEINER, L. J.; MACHADO, G. O. Avaliação da condição de árvores urbanas nos principais parques e praças do município de Irati-PR. Revista da Sociedade Brasileira de Arborização Urbana, Piracicaba, v. 5, n. 2, 105 - 123, 2010.

FLORESTA, Curitiba, PR, v. 50, n. 1, p. 1021 - 1030, jan/mar 2020.

Ivasko Jr, S. et.al.

ISSN eletrônico 1982-4688

1029

DOI: $10.5380 /$ rf.v50 i1.60617 
SHIBGHATALLAH, M. A. H.; KHOTIMAH, S. N.; SUHANDONO, S.; VIRIDI, S.; KESUMA, T. Measuring Leaf Chlorophyll Concentration from Its Color: A Way in Monitoring Environment Change to Plantations. AIP Conference Proceedings, Manchester, v. 1554, n. 1, p. 210 - 213, 2013.

ZHANG, H.; ZHONG, H.; WANG, J.; SUI, X.; XU, N. Adaptive changes in chlorophyll content and photosynthetic features to low light in Physocarpus amurensis Maxim and Physocarpus opulifolius "Diabolo". PeerJ, Londres, v. 4, n. 1, 2016. 